Canadian Journal of Higher Education Revue canadienne d'enseignement supérieur

Volume 45, No. 2, 2015, pages 214 - 228

\title{
Who Is the Successful University Student? An Analysis of Personal Resources
}

\author{
Andrea M. Stelnicki \& David W. Nordstokke \\ University of Calgary \\ Donald H. Saklofske \\ University of Western Ontario
}

\begin{abstract}
A number of factors have been identified in the research literature as being important for student success in university. However, the rather large body of literature contains few studies that have given students the opportunity to directly report what they believe contributes to their success as an undergraduate student. The primary purpose of this study is to explore students' descriptions of the personal resources that they use to succeed while attempting to reach their goals as well as those personal characteristics or obstacles that keep them from reaching their goals. Prominent themes supportive of student success included having a future orientation, persistence, and executive functioning skills such as time management and organization. Results also demonstrate that stress, inadequate academic skills, and distractions are detrimental to student success in university. This study is unique in that it gathers the content data directly from the population of interest; it is one of the few qualitative studies of undergraduate students' self-generated perceptions. Implications for university administrators and academic counsellors and directions for future research are discussed.
\end{abstract}




\section{Résumé}

Des travaux de recherche ont déjà relevé certains facteurs comme étant importants pour la réussite des étudiants de niveau universitaire. Mais bien qu'abondante, la recherche n'a cependant pas donné aux étudiants de premier cycle la possibilité de communiquer directement leur avis quant aux raisons de leur réussite. Le but principal de cette étude est d'explorer les descriptions que les étudiants font des ressources personnelles qu'ils utilisent pour atteindre leurs objectifs et, subsidiairement, les caractéristiques personnelles ou les obstacles qui les empêchent d'atteindre leurs objectifs. Parmi les thèmes importants menant à la réussite des élèves on trouve l'orientation vers l'avenir, la persévérance et des compétences exécutives telles que la gestion du temps et l'organisation. Les résultats démontrent également que le stress, des compétences académiques inadéquates et les distractions représentent des obstacles à la réussite des études universitaires. Cette étude est unique car elle collige les données directement de la population concernée. Elle est aussi l'une des rares études qualitatives portant sur la perception des étudiants de premier cycle. On y examine les conséquences pour les administrateurs universitaires et les conseillers scolaires, de même que les orientations possibles de futures recherches.

In today's society, there is increasing pressure on young adults to attain post-secondary and higher levels of education. This is due in part to the ever-increasing educational requirements for entry-level career positions and promotional opportunities (Bain, Fedynich, \& Knight, 2011; Parker, Saklofske, Wood, \& Collin, 2009). However, between 16\% and $21 \%$ of Canadian post-secondary students fail to complete their studies (Statistics Canada, 2008). Furthermore, many institutions report that up to a quarter of their firstyear students do not return to continue their studies for a second year (Pancer, Hunsberger, Pratt, \& Alisat, 2000). The economic and social consequences of post-secondary students' failure are undeniable. Students who do not complete post-secondary programs or are required to withdraw from university are often limited in their job prospects, earning potential, and lifestyles.

University administrators and policy makers need an efficient way to identify students at risk of early leaving or failing but also to build on their knowledge of student success. A better system for identifying students in need of extra supports would be beneficial for fostering program development for ensuring student retention and success and for improving institutional quality ratings. As well, accurately identifying student needs and risk factors can lead to individualized and specific intervention programs with lifelong positive consequences for all students.

Transitioning from high school to post-secondary learning places significant and novel demands on young people (Tinto, 1993). These adjustment challenges can be stressful for new students (Noel, Levitz, \& Saluri, 1985). The demand for higher levels of independence, initiative, and self-regulation (Bryde \& Milburn, 1990) can be especially difficult for those students when beginning their journey into university life. This would suggest that the need to effectively assist these students is especially evident at the personal level 
(Parker et al., 2009). Further, by understanding the personal characteristics underlying student success and failure, academic advisors and counsellors can use more individualized approaches to pinpoint student areas of strength and weakness as well as build a more supportive and success-oriented environment.

Pre-college factors, such as high school averages and SAT scores, have been linked to college grade point average (GPA) (e.g., Friedman \& Mandel, 2009; Gaskins, 2009) and intent to persist in post-secondary education (e.g., Moses et al., 2011). Thus, it seems obvious that students' academic behaviour, such as attending class and developing effective study skills, would be strongly predictive of success in university. Academic discipline (Allen, Robbins, Casillas, \& Oh, 2008), academic optimism (Solberg Nes, Evans, \& Segerstrom, 2009), course performance (Zlokovich et al., 2003), and attempting a full course load (Attewell, Heil, \& Reisel, 2012) have all been found to contribute to higher GPAs and degree completing. Students who do not persist into their second year of studies often have lower academic resourcefulness skills (Kennett \& Reed, 2009) while those who procrastinate (Seo, 2012), have poor time management skills (Haarala-Muhonen, Ruohoniemi, \& Lindblom-Ylanne, 2011), and are distracted in class (Junco \& Cotton, 2012) tend to have lower grades. Fortunately, research suggests that specific interventions aimed at setting personal academic goals (Morisano, Hirsh, Peterson, Pihl, \& Shore, 2010) and exam preparation and study skills (Noble, Flynn, Lee, \& Hilton, 2007; Strayhorn, 2011) can help to remediate academic behaviour and contribute to higher GPAs. Institutional factors are also important in relation to students' perceptions of themselves and their learning environments. Feelings of disconnect and disengagement can ultimately lead to students wanting to leave school (Lundquist, Spalding, \& Landrum, 2002; Allen \& Smith, 2008; Harms, Roberts \& Winter, 2006). Dissatisfaction with their institution is one of the primary influences on the decision to withdraw (Freeman, Hall, \& Bresciani, 2007) or transfer (Santos Laanan, Starobin, \& Eggleston, 2010). Faculty validation (i.e., when students are recognized, respected, and seen as valued by their instructors) strongly predicts a sense of integration into the academic community and increases students' intent to persist (Barnett, 2011).

Other central components of students' personal characteristics that is important to post-secondary success are personality and conative factors. Self-efficacy and self-rated abilities have been shown to be significantly related to academic performance in college (Brady-Amoon \& Fuertes, 2011). Studies of personality factors contributing to success have shown that extraversion is significantly and positively related to quality of effort put forth in personal and social activities, whereas openness to experience has been demonstrated to be significantly and positively related to quality of effort put into academic activities (Bauer \& Liang, 2003). Openness and locus of control have also been found to be correlated with retention (Moses et al., 2011). Students who are more likely to drop out typically have been shown to have an external locus of control. This can lead to blaming others for their failure, distrust in peers, and a reactive attitude toward suggested selfimprovement (Kingston, 2008). Emotional instability has also been found to be a significant influence on students' thoughts and decisions to leave their institution (Freeman et al., 2007; Parker, Hogan, Eastabrook, Oke, \& Wood, 2006; Gerdes \& Mallinckrodt, 1994).

Another important factor related to student success has to do with the social and family support that students receive. Higher levels of social support may positively impact 
their adjustment to university (Coffman \& Gilligan, 2002); support from both family and peers is important to student success (Purswell, Yazedjian, \& Toews, 2008), and the social support from families may be more important than the financial support they provide, especially for female students (Cheng, Ickles, \& Verhofstadt, 2012).

As summarized above, a number of factors have been identified in the research literature as being important for success in university, yet there is a paucity of studies that ask student's to what they "feel and believe" contributes to their success as undergraduates. Most studies use pre-set questionnaires rather than asking students to find their own words reflecting their thoughts and feelings related to their university experience. Further, even with all the factors currently under examination by researchers, much of the understanding of academic success still remains unknown. Therefore, it is important to ask students directly why they are successful in order to more fully understand what is missing in the explanation of student success. While some students may not have engaged in much reflective self-analysis and others are unable to offer descriptions of the factors related to their successes or failures, our cumulative experience in post-secondary settings certainly indicates that students are likely to be aware of their efforts and the personal resources that help them reach success, as well as those that hinder their ability to be successful. This approach strengthens the validity of the results of the studies described above and allows a more thorough understanding of the various factors important for success in university. An appropriate method to examine this question is through the use of a combined content-frequency analysis.

Content analysis is a technique that is used to provide insight and understanding of a particular phenomenon (Krippendorf, 2013), and together with frequency analysis, it may yield a better understanding of students' own perceptions of the factors contributing to their success while in university. The techniques used in the present study, although not true uses of a content analysis (Krippendorf, 2013), were drawn from the methodology in which words are grouped or clustered to form overall themes that students credit for their successes and their failures in university.

This study explored the personal resources that students report they use to succeed when reaching their goals and the personal characteristics or obstacles they believe are keeping them from reaching their goals. Students were asked to generate their own analyses and views of what key factors allowed them to achieve their goals and succeed at university; that is, students were asked to specify not their success or failure outcomes, but rather the personal resources and factors that contributed to reaching those outcomes. This study was unique in that it gathered the content data as directly described by the population of interest and reflected the kind of lexical approach by, for example, Gordon Allport to describe human traits (1961). Allport suggested that if you want to know something about someone, you should "just ask him" (or her). Additionally, instead of giving students questions to reply to in a semi-structured interview approach, the study asked students to provide accounts of their own resources that would give a richer and more personal view of their road to success. It is hoped that the results from this study will assist researchers and post-secondary personnel in better understanding the important factors for student success and provide the framework for further in-depth exploration. 


\section{Method}

\section{Participants}

Data were collected as part of a multi-year project investigating social and psychological factors that are related to university student success. The final data set used for the analyses was pooled from four separate collections between 2009 and 2011. Participants were undergraduate university students from a variety of programs at a large university in western Canada. The sample consisted of 421 male and 1,006 female students with a mean age of 20.98 years (range $=17-62$ years old). The majority of the students were in their first $(33.4 \%)$ or second (22.8\%) year of study, with the rest of the participants in their third (15.6\%), fourth (14.2\%), or fifth or more (13.2\%) year of study. Participants were recruited from undergraduate programs in various faculties at the university: Arts (33.2\%), Science (31.3\%), Business (7.4\%), Kinesiology (6.9\%), Nursing (6.2\%), Engineering (4.8\%), Medicine (4.6\%), and Education (1.6\%); the remainder had not declared a major or gave no response (3.9\%).

A second group of students were recruited to participate in the Q-sort. These were 19 educational psychology graduate students ( 16 females, 3 males) who were recruited from a graduate-level statistics course and had a knowledge of research methods.

\section{Procedure}

Ethics approval for this study was granted by the university's Conjoint Faculty Research Ethics Board before data collection. Students were invited to participate in the study during regularly scheduled undergraduate lectures. If interested, students were asked to provide email addresses to the research assistant, and the online link to the survey was emailed to them later the same day. Self-response data from the participants was collected using an online survey host (SurveyMonkey ${ }^{\mathrm{TM}}$ ). Once informed consent was given by the participant, they completed a survey of background and demographic variables and were then asked to "provide a list of five words that describe yourself in reaching your goals" and an additional list of "five words that describe what keeps you from reaching your goals." No examples, other guidelines, or character limitations were given to the participants.

\section{Data Analysis}

To determine the number of participants who provided the same word, a frequency analysis was carried out. Counting the frequency of specific responses or words is used in qualitative methods when the frequency is important to directly answering the research question (Krippendorff, 2013). This step provided an indication of the most important and common factors that participants stated were related to their successes and failures in university. Prior to commencing analysis, data used in the frequency analysis were checked for spelling mistakes and for variations of the same word or phrase (e.g., singular and plural versions). For example, procrastinator, procrastination, procrastinating, procrastinater, procastinator, percrastinator, proacrastinate, procastination, and nine other versions of procrastinate were grouped together. After combining misspellings and variations of words, these groups were analyzed for frequency using NVivo 9 qualitative analysis software (QSR International, 2010). 
The words and phrases analyzed using NVivo9 were clustered by the researchers into groups of relatively similar items (e.g., closely related behaviours, attitudes, resources), based on similar categories that are present in the literature. For example, discipline, study skills, and attending class were noted by some participants as important to their success while attending university. These concepts have been studied together (e.g., Allen et al., 2008; Noble et al., 2007; Strayhorn, 2011) and therefore were grouped into a general category of "positive student behaviour." Setting goals, drive, and persistence were grouped together in a general category of "planning for the future," similar to the concept of academic optimism (Solberg Nes et al., 2009). These clusters of words were then presented to graduate students specializing in school and applied psychology, who completed the modified Q-sort.

Q-sort methodology (Stephenson, 1953) is a scaling technique used to understand subjective phenomena from the participant's perspective (McKeown \& Thomas, 1988). In this method, a set of statements are sorted to reflect significance within a number of categories (Block, 1961). The participants in the modified Q-sort were asked to review each of the word clusters (as described above) and produce a title for each category of words. They were free to complete the Q-sort individually or in small groups. They also identified any words they thought didn't fit within the category and stated whether any additional words should be included. The instructions to the Q-sort participants and the word groups can be found in the Appendix.

\section{Results}

The words provided by the participants were analyzed first by frequency and subsequently by category to determine patterns of words that students felt described the most important factors in reaching or not reaching their goals. The frequency analysis yielded a number of words for each category. In total, 6,446 responses were obtained when participants were asked to provide five words that described what helped them reach their goals, and 6,124 responses when asked for five words describing what kept them from reaching their goals. When these responses were examined more closely for misspellings and alternative word endings (e.g., persistent, persistence, persisting, etc.), participants provided in total 158 unique words that described factors helping them reach their goals and 121 unique words that described what kept them from their goals.

After the words were clustered by the researchers and verified by the modified Q-sort participants, 20 word clusters for factors related to reaching their goals and 19 clusters for factors related to keeping students from reaching their goals emerged. Qualitative themes and frequencies are shown in Tables 1 and 2. The frequencies in the second column are based on the content provided by the participants. The third column of each table shows the percentage of Q-sort participants who clustered and labelled each category of words provided by the study participants. For example, $47.4 \%$ of Q-sort participants indicated that "future orientation" was an appropriate title for the group of words that participants most frequently reported as important to their success (see Table 1). Not all Q-sort participants provided a title for every cluster, thus some percentages are lower than others. 
Table 1.

Themes that Helped Students Reach Their Goals

\begin{tabular}{|c|c|c|}
\hline Reaching Your Goals & $f$ & $\begin{array}{c}\text { Endorsed by } \\
\text { Q-sort } \\
\text { participants } \\
(\%)\end{array}$ \\
\hline Future orientation (e.g., determination, focus, financial security) & 1,325 & $47 \cdot 4$ \\
\hline Persistence (e.g., hardwork, dedication, effort) & 1,085 & 47.4 \\
\hline Executive functioning (e.g., time management, planning, preparation) & 605 & 73.7 \\
\hline Motivation (e.g., eagerness, initiative, risk-taking) & 517 & 57.9 \\
\hline Ability (e.g., intelligence, good memory) & 561 & 63.2 \\
\hline Attitude (e.g., optimism, enthusiasm, happiness) & 335 & 31.6 \\
\hline Positive characteristics (e.g., trustworthy, friendly, kind) & 315 & 31.6 \\
\hline Academic skills (e.g., studying, attending class, detail-oriented) & 291 & 21.1 \\
\hline External support (e.g., encouragement, receiving help) & 289 & 52.6 \\
\hline Self-care (e.g., healthy, low stress, sleep) & 238 & $47 \cdot 4$ \\
\hline Interest (e.g., curiosity, inquisitive) & 211 & 10.5 \\
\hline Internal control (e.g., confidence, belief, pride) & 157 & 31.6 \\
\hline Adaptability (e.g., flexibility, resiliency) & 138 & $47 \cdot 4$ \\
\hline Anxiety (e.g., responsibility, guilt, fear) & 136 & 21.1 \\
\hline Community (e.g., engagement, involvement, leadership) & 87 & 42.1 \\
\hline Effective communication (e.g., good listener, assertive) & 72 & 47.4 \\
\hline Awareness (e.g., observant, aware, reflective) & 40 & 15.8 \\
\hline General stress (e.g., no sleep, high stress, concern) & 26 & 15.8 \\
\hline Luck & 13 & 26.3 \\
\hline Withdrawal (e.g., isolation) & 4 & 47.4 \\
\hline
\end{tabular}

Note. Titles for the themes were created by the Q-sort participants. Participants were asked to list five words that described what helped them in reaching their goals. 
Table 2.

Themes that Kept Students Reach Their Goals

Keep You From Reaching Goals

f $\quad$ Endorsed by

Q-sort

participants

(\%)

General stress (e.g., stress, tired, no energy, depression)

$1,182 \quad 26.3$

Academic skills (e.g., low grades, procrastination, late)

935

21.1

Distraction (e.g., other commitments, distraction, job)

$890 \quad 36.8$

Executive functioning (e.g., overworked, time management, inefficient)

526

31.6

Persistence (e.g., lacking effort, lazy, quitter)

470

21.1

Anxiety (e.g., uncertain, holding back)

$351 \quad 10.5$

Self-deprecation (e.g., self-doubt, self-defeating, overconfident)

269

47.4

Negative characteristics (e.g.,judgmental, conflict, impatient)

$261 \quad 36.8$

Interest (e.g., dislike, broad interests)

$247 \quad 15.8$

Future orientation (e.g., no direction, no focus, high expectations)

$214 \quad 26.3$

External support (e.g., no support, pressure, dependent)

Withdrawal (e.g., isolation)

$176 \quad 36.8$

Motivation (e.g., unmotivated, unwilling)

$158 \quad 57 \cdot 9$

Ability (e.g., bad memory, average student, overthinking)

$152 \quad 52.6$

Attitude (e.g., negative, easygoing)

$137 \quad 31.6$

Self-care (e.g., balanced life)

$44 \quad 26.3$

Communication skills (e.g., passive, communication)

$30 \quad 26.3$

Novelty (e.g., inexperience, immature)

$29 \quad 31.6$

Rigidity (e.g., unadaptive, uncreative)

$25 \quad 47.4$

Note. Titles for the themes were created by the Q-sort participants. Participants were asked to list five words that described what was keeping them from reaching their goals. 
The most highly endorsed words by participants in the "reaching your goals" set had a future orientation focus. For example, words that belong to this theme included determination, focus, and drive. The most prominent theme in the "keep you from reaching goals" set was "general stress." This included responses such as no energy, depression, and too tired. Generally, negative words appeared in the set of factors keeping students from reaching their goals. However, a small number of students stated that stress ("general stress"; $f=26$ ) and isolation from others ("withdrawal"; $f=4$ ) were helpful to them in reaching their goals (Table 1). This is in contrast to the majority of students, who stated that stress ("general stress"; $f=1,182$ ) and isolation ("withdrawal"; $f=176$ ) kept them from reaching their goals (Table 2).

For reaching goals, participants focused on and reported more internal or personal characteristics, with the exception of one category, "external support." Non-internal characteristics were more likely to be endorsed when participants were asked what kept them from their goals. These included distraction (e.g., job, other commitments; $f=890$ ) and external support (e.g., pressure from parents; $f=197$ ). Thus, the participants in this sample recognized their own contribution to their successes and, less so, to their failures.

\section{Discussion}

The purpose of this study was to better understand how students describe those personal characteristics and external factors that help or hinder them in reaching their goals at university. These self-reported data are an important component in developing a comprehensive model of student success. Students were asked to indicate what helped them reach their goals and what kept them from reaching their goals. When students report what they need help with and what they currently use to help themselves, university advisors, academic counsellors and faculty would appear to gain much more useful information to provide the directed support and assistance that at least a portion of this population requires to be successful.

In this study, factors such as having a future orientation, persistence, and strong executive functioning skills were listed as the most important for undergraduate students to reach their goals while attending university. Students who set goals for their undergraduate experience also have a higher probability of maintaining a full course load (Morisano et al., 2010), subsequently leading to a higher likelihood of graduating with a degree.

Stress, poor academic skills (e.g., not attending class and procrastinating), and distraction were the most salient factors that kept undergraduate students from reaching their goals, with general stress noted by the majority of the participants. Stress has been shown to be negatively related to regulating emotions and focus on tasks (Austin, Saklofske, \& Mastoras, 2010), which may lead students to neglect to consider or revisit the goals they had originally set for themselves. In fact, students who set goals and reflect on them tend to have higher GPAs (Morisano et al., 2010). Stress and distraction are likely to be closely related or interactive, which likely leads to poor academic skills, such as missing classes and leaving studying or assignments to the last minute. This may explain why these three items were endorsed so frequently.

Interestingly, in each set of responses (i.e., reaching goals or not reaching goals), participants provided similar themes, but words were commonly phrased in the opposite from one set to the other. For example, some students indicated that no support 
from their families or too much pressure from their families impeded their success; but a healthy level of support facilitated students' success. Generally, support from family and peers is related to higher levels of life satisfaction (Coffman \& Gilligan, 2002), greater persistence (Wells, 2008), and better GPAs in college (Swenson Goguen, Hiester, \& Nordstrom, 2010). However, various levels of support have not been adequately explored in the literature. The findings from this study suggest that different levels of social support may have different implications for university students, especially support emanating from the family. It may be that students who have no financial or personal support from their family have to find part-time or full-time employment during their education while worrying about their accumulating debt, or that such students feel alone or even alienated. Alternatively, students who see their families as being over-involved could feel pressure to take classes to satisfy their parents, are constantly reminded about their school choices and marks, and work at a level that is detrimental to their success in an attempt to appease family. Students who have a healthy level of support from their family probably feel autonomous but still have someone to turn to in times of emotional and/or financial need. Certainly such latent factors as personality, but also age, gender, and similar characteristics are likely to mediate or even moderate these self-perceptions.

The factors identified by the students in this study do not fully overlap with the factors in the literature. For example, the category most identified by students as contributing to their success was having a future orientation, which included factors such as determination and focus. These factors have not been specifically identified in previous studies, although a future orientation is obviously important to sustain motivation and interest in present activities. The literature tends to focus on more general categories like motivation, attitude, academic skills, and external support, which were also recognized by the participants in this study. Thus, there appears to be room to expand what is currently being measured in the field of student success.

\section{Limitations}

This study is not without limitations. The questions posed to the participating students were about the personal resources they felt contributed to their successes in reaching their goals and failures in not reaching their goals while attending university. However, the research literature on student success primarily focuses on defining success not as reaching personal goals, but as academic achievement or GPA and persistence to the following year or graduation rates. This study was not intended to confirm that students' goals are equivalent to high GPAs or graduating from their degree programs, but rather to offer a further examination of those factors that students attribute the achievement of their personal goals and their success while in university. Thus, specific outcomes such as GPA were not the focal point of the students' responses. As such, it may be that students who are successful, who graduate and obtain high GPAs, use different words or categories than students who have difficulty achieving high grades or reaching graduation. Further, it is unclear whether students were responding specifically about their academic goals or whether they were also including goals they set for themselves in general. It would be beneficial to continue this line of inquiry.

The generalizability of the study's findings, at least until further studies are conducted. Although the sample was obtained from a variety of programs and years of study, the re- 
spondents were predominantly female. Additionally, the findings might not be replicated at other types or sizes of post-secondary institutions. As such, this study should be replicated with a larger and more representative sample of students from various types of institutions.

The request for five words or phrases may have limited participants in providing elaborate discussions of what helped or hindered them in university. There is a definite possibility that the words or short phrases that they provided were not interpreted by the researcher exactly in the same way the participants intended; however, when students attribute success to intelligence, persistence, or interest, such a large frequency of these words suggests a relatively common meaning. We also recognize that some students may not have the insight into what specifically helped them achieve success or may not be able to communicate or operationalize it. Additionally, the definitions of categories may not be exactly the same as those identified in the literature or as participants intended. While the researchers who categorized the factors before presenting them to the graduate students for the modified Q-sort may have missed the intent of what the participants were trying to get across, a having multiple raters to verify and agree on the label name for the word cluster likely provided a greater degree of stability and robustness in the results.

\section{Implications and Future Directions}

The results of this study provide another lens for better understanding how students reach their goals and succeed at university. These categories may be used as a framework by academic advisors and counsellors to guide discussions that could pinpoint areas of further exploration when students present with academic concerns. Another side to this research would be to compare university administrators' and advisors' perceptions of the factors associated with student success to determine the congruence or disconnect between students and staff. The results of this study should be replicated and empirically linked with external indicators of success (e.g., graduation, GPA) if they are to have significant implications for researchers, policy makers, educators, advisors, and university administrators as well as parents and support persons. Finally, it is hoped this study presents an insightful and contextual understanding that reflects how students frame and attribute to the 'causes' for their reaching their goals (or not) within the post-secondary education setting. The information obtained in students' own words can provide a more focused basis for academic support staff to assist students to achieve their academic and personal goals by focusing on the students' perceptions of their greatest challenges and utilizing their identified strengths to build capacity. In turn, this understanding will help to guide the university community in achieving increased student retention and success.

\section{References}

Allen, J., Robbins, S. B., Casillas, A., \& Oh, I. (2008). Third-year college retention and transfer: Effects of academic performance, motivation, and social connectedness. Research in Higher Education, 49(7), 647-664. http://dx.doi.org/10.1007/s11162-0089098-3

Allen, J. M., \& Smith, C. L. (2008). Faculty and student perspectives on advising: Implications for student dissatisfaction. Journal of College Student Development, 49(6), 609-624. http://dx.doi.org/10.1353/csd.o.0042 
Allport, G. W. (1961). Pattern and growth in personality. New York, NY: Holt, Rinehart \& Winston.

Attewell, P., Heil, S., \& Reisel, L. (2012). What is academic momentum? And does it matter? Educational Evaluation and Policy Analysis, 34(1), 27-44. http://dx.doi. org/10.3102/0162373711421958

Austin, E. J., Saklofske, D. H., \& Mastoras, S. M. (2010). Emotional intelligence, coping and exam-related stress in Canadian undergraduate students. Australian Journal of Psychology, 62(1), 42-50. http://dx.doi.org/10.1080/00049530903312899

Bain, S., Fedynich, L., \& Knight, M. (2011). The successful graduate student: A review of the factors for success. Journal of Academic and Business Ethics, 3, 1-9. Retrieved from http://www.aabri.com/manuscripts/10569.pdf

Barnett, E. A. (2011). Validation experiences and persistence among community college students. Review of Higher Education, 34(2), 193-230. http://dx.doi.org/10.1353/ rhe.2010.0019

Bauer, K. W., \& Liang, Q. (2003). The effect of personality and precollege characteristics on first-year activities and academic performance. Journal of College Student Development, 44(3), 277-290. http://dx.doi.org/10.1353/csd.2003.0023

Block, J. (1961). The Q-sort method in personality assessment and psychiatric research. Springfield, IL: Charles C. Thomas.

Brady-Amoon, P., \& Fuertes, J. N. (2011). Self-efficacy, self-rated abilities, adjustment, and academic performance. Journal of Counseling \& Development, 89(4), 431-438. http://dx.doi.org/10.1002/j.1556-6676.2011.tbo2840.x

Bryde, J. F., \& Milburn, C. M. (1990). Helping to make the transition from high school to college. In R. L. Emans (Ed.), Understanding undergraduate education (pp. 203-213). Vermillion, SD: University of South Dakota Press.

Cheng, W., Ickles, W., \& Verhofstadt, L. (2012). How is family support related to students' GPA scores? A longitudinal study. Higher Education, 64(3), 399-420. http:// dx.doi.org/10.1007/s10734-011-9501-4

Coffman, D. L., \& Gilligan, T. D. (2002). Social support, stress, and self-efficacy: Effects on students' satisfaction. Journal of College Student Retention: Research, Theory, and Practice, 4(1), 53-66. http://dx.doi.org/10.2190/BV7X-F87X-2MXL-2B3L

Freeman, J. P., Hall, E. E., \& Bresciani, M. J. (2007). What leads students to have thoughts, talk to someone about, and take steps to leave their institution? College Student Journal, 41(4), 755-770. Retrieved from http://projectinnovation.biz/csj_2006.html

Friedman, B. A., \& Mandel, R. G. (2009). The prediction of college student academic performance and retention: Application of expectancy and goal setting theories. Journal of College Student Retention, 11(2), 227-246. http://dx.doi.org/10.2190/CS.11.2.d

Gaskins, B. P. (2009). A Ten-Year Study of the Conditional Effects on Student Success in the First Year of College. Retrieved from ProQuest Digital Dissertations. (AAT 3371000)

Gerdes, H., \& Mallinckrodt, B. (1994). Emotional, social, and academic adjustment of college students: A longitudinal study of retention. Journal of Counseling and Development, 72(3), 281-288. http://dx.doi.org/10.1002/j.1556-6676.1994.tboo935.x 
Haarala-Muhonen, A., Ruohoniemi, M., \& Lindblom-Ylanne, S. (2011). Factors affecting the study pace of first-year law students: In search of study counselling tools. Studies in Higher Education, 36(8), 911-922. http://dx.doi.org/10.1080/03075079.201 0.488722

Harms, P. D., Roberts, B. W., \& Winter, D. (2006). Becoming the Harvard man: Personenvironment fit, personality development and academic success. Personality and Social Psychology Bulletin, 32(7), 851-865. http://dx.doi.org/10.1177/0146167206287720

Junco, R., \& Cotton, S. R. (2012). No A 4U: The relationship between multitasking and academic performance. Computers \& Education, 59(2), 505-514. http://dx.doi. org/10.1016/j.compedu.2011.12.023

Kennett, D. J., \& Reed, M.J.(2009). Factors influencing academic success and retention

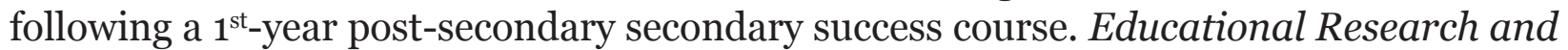
Evaluation: An International Journal on Theory and Practice, 15(2), 153-166. http:// dx.doi.org/10.1080/13803610902804382

Kingston, E. (2008). Emotional competence and drop-out rates in higher education. Educationand Training,50(2),128-139.http://dx.doi.org/10.1108/00400910810862119

Krippendorff, K. (2013). Content analysis: An introduction to its methodology ( ${ }^{\text {rd }}$ ed.). Thousand Oaks, CA: Sage.

Lundquist, C., Spalding, R. J., \& Landrum, R. E. (2002). College student's thoughts about leaving the university: The impact of faculty attitudes and behaviors. Journal of College Student Retention: Research, Theory and Practice, 4(2), 123-133. http://dx.doi. org/10.2190/FLAL-7AM5-Q6K3-L40P

McKeown, B., \& Thomas, D. (1988). Q Methodology. Newbury Park, CA: Sage.

Morisano, D., Hirsh, J. B., Peterson, J. M., Pihl, R. O., \& Shore, B. M. (2010). Setting, elaborating, and reflecting on personal goals improves academic performance. Journal of Applied Psychology, 95(2), 255-264. http://dx.doi.org/10.1037/a0018478

Moses, L., Hall, C., Wuensch, K., De Urquidi, K., Kauffman, P., Swart, W., ... Dixon, G. (2011). Are math readiness and personality predictive of first-year retention in engineering? Journal of Psychology, 145(3), 229-245. http://dx.doi.org/10.1080/0022 3980.2011.557749

Noble, K., Flynn, N. T., Lee, J. D., \& Hilton, D. (2007). Predicting successful college experiences: Evidence from a first year retention program. Journal of College Student Retention: Research, Theory and Practice, 9(1), 39-6o. http://dx.doi.org/10.219o/684142JX-X170-8177

Noel, L., Levitz, R., \& Saluri, D. (1985). Increasing student retention: Effective programs and practices for reducing dropout rate. San Francisco, CA: Jossey-Bass.

Pancer, S. M., Hunsberger, B., Pratt, M. W., \& Alisat, S. (2000). Cognitive complexity of expectations and adjustment to university in the first year. Journal of Adolescent Research, 15, 38-57. 
Parker, J. D. A., Hogan, M. J., Eastabrook, J. M., Oke, A., \& Wood, L. M. (2006). Emotional intelligence and student retention: Predicting the successful transition from high school to university. Personality and Individual Differences, 41(7), 1329-1336. http://dx.doi.org/10.1016/j.paid.2006.04.022

Parker, J. D. A., Saklofske, D. H., Wood, L. M., \& Collin, T. (2009). The role of emotional intelligence in education. In C. Stough, D. H. Saklofske, \& J. D. A. Parker (Eds.) Assessing emotional intelligence: Theory, research, and applications (pp. 239-255). New York, NY: Springer.

Purswell, K. E., Yazedjian, A., \& Toews, M. L. (2008). Students' intention and social support as predictors of self-reported academic behaviors: A comparison of first- and continuing-generation college students. Journal of College Student Retention: Research, Theory and Practice, 10(2), 191-206.

QSR International. (2010). NVivo 9 [computer software]. Doncaster, Australia: QSR International.

Santos Laanan, F., Starobin, S. S., \& Eggleston, L. E. (2010). Adjustment of community college students at a four-year university: Role and relevance of transfer student capital for student retention. Journal of College Student Retention: Research, Theory and Practice, 12(2), 175-209. http://dx.doi.org/10.2190/CS.12.2.d

Seo, E. H. (2012). Cramming, active procrastination, and academic achievement. Social Behavior and Personality, 4O(8), 1333-1340. http://dx.doi.org/10.2224/ sbp.2012.40.8.1333

Solberg Nes, L., Evans, D. R., \& Segerstrom, S. C. (2009). Optimism and college retention: Mediation bymotivation, performanceandadjustment.JournalofAppliedSocial Psychology, 39(8), 1887-1912. http://dx.doi.org/10.1111/j.1559-1816.2009.00508.x

Statistics Canada. (2008). Postsecondary education - Participation and dropping out: Differences across university, college, and other types of postsecondary institutions. Retrieved from http://www.statcan.gc.ca/pub/81-595-m/81-595-m2008070-eng.pdf

Stephenson, W. (1953). The study of behavior: Q-technique and its methodology. Chicago, IL: University of Chicago Press.

Strayhorn, T. L. (2011). Increasing underrepresented students' prep for college through a summer bridge program. American Behavioral Scientist, 55(2), 142-159. http://dx.doi. org/10.1177/0002764210381871

Swenson Goguen, L. M., Hiester, M. A., \& Nordstrom, A. H. (2010). Associations among peer relationships, academic achievement, and persistence in college. Journal of College Student Retention: Research, Theory and Practice, 12(3), 319-337. http:// dx.doi.org/10.2190/CS.12.3.d

Tinto, V. (1993). Leaving college: Rethinking causes and cures of student attrition ( $2^{\text {nd }}$ ed.) Chicago: University of Chicago Press.

Wells, R. (2008). Social and cultural capital, race, and ethnicity, and college student retention. Journal of College Student Retention: Research, Theory and Practice, 1O(2), 103-128. http://dx.doi.org/10.2190/CS.10.2.a 
Zlokovich, M. S., Crites, D., Bingham, J., Buck, L., Burt, S., Goings-Vogelsang, C., ... Steiner, A. (2003). How are first-year student study habits and grade predictions related to semester and cumulative grades, long-term retention, and graduation? Journal of the First-Year Experience, 15(1), 77-104. Retrieved from http://fyesit.metapress.com/ content/120201/?sortorder=asc

\section{Contact Information}

Andrea Stelnicki

School and Applied Child Psychology

University of Calgary

amstelni@ucalgary.ca

Andrea Stelnicki is a doctoral student in School and Applied Child Psychology at the University of Calgary. The research presented in this article contributed to a portion of her MSc thesis, completed in 2013. Her dissertation work focuses on the impact of the family system on students' behavioural and social outcomes and academic achievement.

David Nordstokke conducts research across a variety of educational and psychological contexts. Part of his research is focused on applied methods that include: (1) the design of research studies, (2) the collection and statistical analysis of data, and (3) the interpretation and dissemination of results. A portion of his research focuses on the investigation of psychological and educational variables (e.g., resilience). In addition, a considerable proportion of the research he is involved in is interdisciplinary and collaborative in nature and much of his current research focuses on applying statistical models to data that are gathered in a number of disciplines.

Don Saklofske is a professor in the Department of Psychology, the University of Western Ontario. His research focuses on personality, intelligence, and individual differences including emotional intelligence and resiliency. He is a Fellow of the Association for Psychological Science and the Canadian Psychological Association and editor for several journals and book series. He has published more than 30 books and 200 book chapters and journal articles. 